\title{
MALANG CORRUPTION WATCH SEBAGAI GERAKAN MASYARAKAT SIPIL GUNA MEMBANGUN BUDAYA ANTI-KORUPSI DI DAERAH
}

\author{
Fahdian Rahmandani ${ }^{1}{ }^{*}$, Samsuri ${ }^{2}$ \\ ${ }^{1}$ Graduate Student of Pendidikan Pancasila dan Kewarganegaraan, Universitas Negeri Yogyakarta, Indonesia \\ ${ }^{2}$ Department of Pendidikan Pancasila dan Kewarganegaraan, Universitas Negeri Yogyakarta, Indonesia
}

ARTICLE INFORMATION

Submitted : 06 January 2019

Review : 05 April 2019

Accepted : 12 May 2019

Available online: June 2019

\section{KEYWORDS}

Anti-Corruption, Civil Society Movement, Malang Corruption Watch, Citizenship Education, AntiCorruption Culture

\section{CORRESPONDENCE}

*E-mail: fahdianrahmandani.2017@student.uny.ac.id

\section{A. PENDAhULUAN}

$\mathrm{K}$ orupsi menjadi fenomena sosial yang kronis dan harus dipecahkan. Tindakan korup telah menggerogoti akuntabilitas diri seseorang dan pemerintah dalam memberikan pelayanan kepada publik. Korupsi merupakan tindakan buruk dan sebagai ancaman terhadap pemerintahan demokratis. Korupsi juga menaruh ancaman terhadap stabilitas politik dan pembangunan berkelanjutan (Quah, 2017:135).

Sulit untuk menjelaskan korupsi secara utuh, karena korupsi merupakan masalah yang kuno dan memiliki fleksibilitas di sektor apapun sehingga penjelasan tentang korupsi hanya tertuju pada penyimpangan perilaku negatif. Selanjutnya Chowdhury, Desai, \& Audretsc (2018:41) membagi korupsi ke dalam beberapa jenis. Ada korupsi besar (grand corruption) merupakan tindakan elite politik dimana mereka mengeksploitasi kekuatan mereka untuk membuat kebijakan; korupsi birokrasi (bureaucratic corruption) adalah keterlibatan dalam perilaku

\section{A B S T R A C T}

Corruption is a problem that threatens various sectors, such as politics, education, economy, culture, and health. At the area level, corruption cases are a threat that is difficult to detect because of the absence of ad-hoc institutions in conducting surveillance. Therefore, it takes an independent civil society at the area level to enable monitoring and voiced the idea of anticorruption. This study aims to determine the role of nongovernmental organizations namely Malang Corruption Watch in building an anti-corruption culture in Malang Raya. The method used in writing this article is a literature study. The results of this study indicate that Malang Corruption Watch is a non-governmental organization that has an independent nature. In overcoming the problem of communal corruption, Malang Corruption Watch provides citizenship education to the people's in the form of people political education, public schools, citizen forums, community groups guarding public services, campaigning for anti-corruption movements, and anti-corruption schools to increase the critical power of citizens in addressing the middle public problems happen. Furthermore, there are several posts complaints that are provided so that citizens can easily express their aspirations to realize an anti-corruption culture.

korupsi oleh para birokrat tingkat rendah dan atasan mereka, dan korupsi legislatif (legislative corruption) juga disebut korupsi politik adalah ketika sumber daya moneter digunakan untuk mempengaruhi sikap para legislator, atau dalam bahasanya Kubbe dan Engelbert (2018: 71) agen politik memanipulasi dan memodifikasi lembaga pemerintah serta sistem politik untuk mempertahankan kekuasaan atau untuk mendapatkan keuntungan materi. Jiang (2018: 12) coba menguraikan korupsi dalam dua sudut pandang, yaitu antara sistemis dan sistematis. Korupsi sistemis maksudnya produk dari sistem administrasi yang lemah dan tidak adanya lembaga ad-hoc yang mengawasi sehingga menjadi endemik terhadap sistem. Sedang korupsi sistematis dianggap sebagai kejahatan terorganisasi, ada tujuan untuk kepentingan pribadi dan kelompok dalam menumbangkan desain sistem politik atau memanipulasi sistem politik demi sebuah kepentingan.

Sebenarnya alasan terjadinya korupsi dapat ditinjau dari beberapa faktor. Chowdhury, Desai, 
\& Audretsc (2018: 43) menjelaskan secara singkat alasan dibalik tindakan korupsi disebabkan karena sistem demokrasi yang digunakan di beberapa negara masih banyak celah sehingga lembaga-lembaga politik dapat dimasuki oleh para politisi yang korup. Pada intinya tingkat pembangunan ekonomi dan lingkungan politik menjadi alasan kuat kenapa kebocoran terjadi oleh tindakan korupsi. Faktor lain penyebab terjadinya korupsi coba dipaparkan oleh KPK berdasarkan studi yang telah dilakukan kepada pelaku korupsi, mahasiswa, dan aparatur sipil negara (ASN). Penyebab korupsi dalam sudut pandang KPK penting untuk disorot adalah faktor internal individu, karena lemahnya moral dan etika dalam diri seseorang, gaya hidup mewah, persepsi tentang korupsi yang terbatas, permisif; dan faktor budaya permisif, mendahulukan kepentingan golongan (solidaritas buta) (Tim Penyusun Laporan KPK, 2017: 302).

Korupsi merupakan persoalan yang tidak dapat dipisahkan dari berbagai sektor, seperti politik, pendidikan dan moral, budaya, kesehatan, kelembagaan dan ekonomi. Negara Indonesia dalam Corruption Perceptions Index (CPI) Tahun 2016 diterbitkan oleh Transparency International (2017) menempati urutan ke 90 dari 172 negara dengan skor 37 (pada rentangan 0-100 poin). Poin 0 berarti menunjukkan sangat korup dan poin 100 menunjukkan persepsi sangat bersih (Transparency International, 2017). Bahkan pada tahun berikutnya, Indonesia melorot ke posisi 96 meski memiliki nilai yang sama (Transparency International, 2018). Dari data tersebut menunjukkan bahwa tingkat korupsi di Indonesia masih terbilang buruk. Secara sejarah pengalaman Indonesia dalam kejahatan ini memang begitu kelam.

Korupsi saat ini merupakan realitas tindakan penyimpangan norma sosial dan hukum pada tingkat kulminasi. Korupsi menghasilkan dampak yang menghambat pembangunan dalam berbagai sektor. Dalam karyanya Quah (2017:135) memaparkan jika korupsi merupakan tindakan yang buruk dan sebagai ancaman terhadap pemerintahan yang demokratis. Korupsi juga menaruh ancaman terhadap stabilitas politik dan pembangunan berkelanjutan.

Sebuah studi coba yang menjelaskan kenapa korupsi memberikan dampak dengan membudayanya karakter yang korup, pembangunan terhambat, dan pelayanan tidak maksimal sehingga kejahatan ini begitu diperangi sampai dengan saat ini. Pertama, studi dalam sektor pendidikan yang dilakukan oleh Deliversky (2016:142) menyebutkan jika sektor pendidikan dapat di korupsi dengan beberapa cara, diantaranya melalui fungsi pendidikannya, penyediaan barang dan jasa, buruknya kompetensi profesionalisme, dan melalui perpajakan dan properti. Beberapa cara tersebut coba diperjelas dalam kecenderungan korupsi di bidang perencanaan dan manajemen, seperti sistem informasi; pembangunan sekolah; rekrutmen; promosi (termasuk sistem intensif) dan pengangkatan guru; penyediaan dan distribusi peralatan dan buku teks; alokasi tunjangan khusus (beasiswa); ujian dan ijazah; dan kegiatan-kegiatan diluar sekolah. Menurut Deliversky konsekuensi korupsi dalam pendidikan akan menyebabkan pemborosan sumber daya keuangan, serta tujuan pendidikan yang sejatinya untuk mengembangkan kemampuan siswa kurang maksimal karena terjadinya disorientasi tujuan pembelajaran, terjadinya manipulasi bakat siswa, dan yang lebih parah adalah siswa menganggap sebuah tindakan korupsi sebagai tindakan yang wajar untuk dilakukan.

Hasil identifikasi ICW selama 10 tahun (2006-2015) memaparkan bahwa kasus korupsi di sektor pendidikan sebanyak 425 kasus menyebabkan kerugian negara mencapai Rp. 1,3 Triliun dan nilai suap Rp. 55 miliar. Lima objek dana yang paling banyak di korupsi meliputi dana khusus alokasi (DAK); dana sarana dan prasarana sekolah; bantuan operasional sekolah (BOS); dan infrastruktur sekolah serta buku. Sedangkan pada sektor kesehatan, 93\% tindakan korupsi berkutik dalam pengolahan dana program kuratif seperti pengadaan alat kesehatan, jaminan kesehatan, pembangunan rumah sakit/puskesmas (laboratorium), dan obatobatan. Dari laporan ICW objek paling masif di korupsi adalah dana pengadaan alat kesehatan sebanyak 43 kasus dengan kerugian mencapai 442 miliar (Indonesia Corruption Watch, 2016).

Beberapa dampak yang diakibatkan dari tindakan korupsi tersebut memunculkan isu-isu sosial kemasyarakatan lainnya seperti terjadinya ketimpangan sosial, ekonomi, politik, pendidikan, dan kesejahteraan sosial. Senada bahwa korupsi memang sebuah kejahatan yang harus diperangi, Quah (2017:135) menjelaskan jika korupsi akan menghambat kemajuan dan perkembangan. Baginya korupsi akan melahirkan ketidakmampuan, ketidakmakmuran, kehambaran dalam sebuah pembangunan, melahirkan nilai yang tidak etis, serta melahirkan sifat serakah dan rakus pada diri seseorang.

Selain itu tindakan korupsi memiliki dampak yang masif dan sangat kompleks yang menyerang berbagai sektor. Pertama, sektor ekonomi dengan seperti lesunya pertumbuhan ekonomi dan investasi, penurunan produktivitas, rendahnya kualitas barang dan jasa bagi publik dll. Kedua, sektor sosial dan kemiskinan masyarakat, korupsi mengakibatkan mahalnya harga jasa dan pelayanan publik, pengentasan kemiskinan berjalan lambat, terbatasnya akses bagi masyarakat miskin dll. Ketiga, sektor politik dan demokrasi dengan munculnya kepemimpinan korup, hilangnya kepercayaan publik pada demokrasi, menguatnya plutokrasi atau sistem politik yang dikuasai oleh pemilik modal/kapitalis 
dll. Keempat, sektor ketahanan dan keamanan misalnya dengan kerawanan pertahanan keamanan nasional karena lemahnya alutsista dan sumber daya manusia (SDM), lemahnya garis batas negara, dan menguatnya sisi kekerasan dalam masyarakat. Dan terakhir kelima, sektor lingkungan dengan semakin menurunnya kualitas lingkungan dan menurunnya kualitas hidup (Puspito, dkk, 2011: 55-70). Permasalahan korupsi ini menjadi sumber persoalan yang tidak dapat dipisahkan dari kehidupan bernegara. Dalam memerangi kejahatan tersebut dibutuhkan keterlibatan seluruh warga negara (civic engagement).

Peran warga negara, baik secara individu maupun secara kelompok sangat dibutuhkan dalam menjawab problematika yang terjadi di tengah masyarakat tersebut. Melalui lembagalembaga kemasyarakatan, masyarakat akan mampu memberikan pengaruhnya, baik dalam perumusan dan pengambilan kebijakan publik yang merupakan karakteristik dari sebuah negara demokrasi. Hal itu dapat dilakukan melalui partisipasi masyarakat dengan membentuk asosiasi-asosiasi masyarakat kewargaan yang sering disebut sebagai gerakan non-pemerintah atau Non Government Organization (NGO).

Peran dari LSM secara tidak sadar akan membentuk sebuah budaya kewarganegaraan yang khas dan mewujudkan tujuan dari pendidikan kewarganegaraan yaitu dengan menciptakan masyarakat yang virtue. Melalui pengembangan civil society yang kuat dan mandiri, LSM akan turut mengambil peran dalam memperbaiki kondisi yang ada. Salah satunya adalah Malang Corruption Watch, lembaga swadaya masyarakat yang memiliki misi mewujudkan pemerintahan yang bersih dari korupsi, melalui tindakan monitoring, investigasi, advokasi, serta pendidikan publik. MCW menjadi gerakan moral dan gerakan sosial di Malang Raya.

Wilayah Malang Raya akhir-akhir ini menjadi zona merah perihal kasus korupsi. Dalam Badan Pekerja MCW tahun 2017 ada 9 temuan tindakan korupsi dalam kasus penyertaan modal PDAM di Kota Malang yang diprakarsai oleh Ketua DPRD Kota Malang dengan kerugian negara mencapai 1,6 miliar. Selanjutnya operasi tangkap tangan (OTT) Walikota Batu dalam kasus pengadaan meubelair 5,7 M dengan ditemukan 13 indikasi tindakan korupsi yang dilakukan dan kerugian negara mencapai 2,24 miliar. Disusul pada tahun 2018 yang menghebohkan masyarakat Malang Raya dengan ditangkapnya Wali Kota Malang beserta beberapa anggota DPRD Kota Malang dalam indikasi terjadinya suap APBD Kota Malang tahun 2015. Tidak menunggu waktu lama, hasilnya pada tahun 2018 KPK menetapkan walikota dan 41 DPRD Kota Malang sebagai tersangka dalam tindakan persekutuan penetapan APBD murni tahun 2015. Selain itu, di daerah lain di Malang Raya seperti Kota Batu dan Kabupaten Malang masing-masing kepala daerah turut terjerat kasus suap pengadaan barang dan jasa dengan menerima suap pengadaan meubelair (furniture) di Pemerintah Kota Batu tahun 2017 dan gratifikasi DAK dengan indikasi menerima suap terkait penyediaan sarana Dinas Pendidikan sebesar Rp. 3,45 miliar dan menerima gratifikasi sekitar 3,55 miliar (Badan Pekerja MCW, 2017; 2018).

Penyimpangan-penyimpangan perilaku pejabat publik menunjukkan telah terjadi distorsi terhadap peran yang seharusnya dijalankan sehingga masyarakat sebagai relasi pemerintah dan Malang Corruption Watch sebagai partnership masyarakat dibutuhkan untuk menunjukkan reaksinya terhadap tindakan-tindakan korupsi oleh oknum yang tidak bertanggung jawab. Pertama, tujuan penulisan artikel ini dimaksudkan untuk mengetahui peran dari Malang Corruption Watch dalam membentuk jaringan masyarakat sipil; kedua, untuk mengetahui bentuk-bentuk pendidikan kewarganegaraan yang diberikan Malang Corruption Watch kepada masyarakat; ketiga, untuk mengetahui program-program yang dilakukan dalam membangun kesadaran antikorupsi dan meningkatkan keterlibatan masyarakat guna menjawab permasalahan korupsi di Malang Raya.

\section{B. METODE PENELITIAN}

$\mathrm{M}$ etode yang digunakan dalam penulisan artikel ini menggunakan metode kepustakaan (library research). Studi pustaka atau jenis penelitian kepustakaan dapat diartikan sebagai serangkaian kegiatan yang berkenaan dengan pengumpulan data pustaka, membaca dan mencatat serta mengolah bahan penelitian (Zed, 2008: 3). Bahan penelitian dalam artikel ini berupa sumber sekunder atau data yang berasal dari laporan Malang Corruption Watch tahun 2017 dan 2018 yang menjelaskan fenomena korupsi didaerah Malang Raya. Didukung dengan berbagai sumber literatur berupa hasil penelitian dan laporan tentang korupsi dari instansi internasional, nasional, serta berbagai referensi kajian teori dari berbagai jurnal dan buku. Tegasnya studi pustaka membatasi kegiatannya hanya pada bahanbahan koleksi buku tanpa memerlukan penelitian di lapangan (Zed, 2008: 1-2).

\section{HASIL DAN PEMBAHASAN \\ 1. Malang Corruption Watch Sebagai Gerakan Masyarakat Sipil}

$\mathrm{K}$

eberadaan Malang Corruption Watch yang berawal dari komunitas diskusi telah berjalan sebelum reformasi 1998 
berlangsung. Dalam situs web resmi MCW dijelaskan jika Malang Corruption Watch berevolusi menjadi lembaga swadaya masyarakat pada 31 Mei 2000 yang terinspirasi oleh keberadaan Indonesia Corruption Watch (ICW) sehingga di wilayah Malang Raya di inisiasi untuk membentuk lembaga anti-korupsi yang berbasiskan pada masyarakat..

Visi dari Malang Corruption Watch yaitu mengharapkan terciptanya masyarakat madani yang humanis, beradab, bermartabat, dan berdaulat dengan mengupayakan terciptanya tatanan birokrasi, politik, ekonomi dan hukum yang bebas dari korupsi, kolusi, dan nepotisme. Sedang untuk misi lembaga ini yaitu melakukan monitoring dan investigasi kasus korupsi serta melakukan pendidikan publik untuk membangun gerakan sosial anti korupsi melalui pembentukan zona anti korupsi.

Pada situs resmi lembaga ini dijelaskan bahwa penguatan gerakan rakyat melalui lembaga masyarakat sipil menjadi agenda penting dalam mewujudkan birokrasi, politik, ekonomi yang akuntabel dan terbebas dari korupsi, kolusi, dan nepotisme (KKN). Khusus wilayah Malang Raya, Malang Corruption Watch menjadi ujung tombak dalam memerangi kejahatan yang korup tersebut. Melalui pendidikan publik, gerakan sosial anti korupsi menjadi wadah masyarakat dalam membangun zona anti korupsi di Malang Raya.

Malang Corruption Watch sebagai gerakan masyarakat sipil memiliki beberapa agendaagenda yang dilakukan seperti kegiatan monitoring, investigasi, kampanye, pendidikan publik, dan advokasi kasus-kasus korupsi yang terjadi di wilayah Kota Malang, Kabupaten Malang, dan Kota Batu. Dalam situs resminya disebutkan jika seluruh agenda yang dilakukan MCW berorientasi untuk membentuk gerakan sosial yang berbadan ditengah-tengah kehidupan masyarakat sebagai bagian dari proses demokratisasi sistem politik maupun ekonomi. Harapannya MCW dapat mendorong terbentuknya sebuah perangkat nilai dan norma sosial yang adil, humanis, dan berdaulat.

Adapun kode etik dalam lembaga gerakan masyarakat sipil "Malang Corruption Watch" sebagai berikut. 1) Menjunjung tinggi prinsip kemanusiaan, 2) Tidak boleh menerima sumbangan program dari objek pantau (badan eksekutif, legislatif, dan yudikatif), 3) Dalam satu kegiatan badan kerja yang bertugas minimal dua orang, dan 4) Menganut prinsip transparansi, akuntabilitas, dan partisipatif.

Pada tahun 2017 dalam Laporan Akhir Tahun 2017 Malang Corruption Watch terdapat tiga rencana strategis yang disusun oleh MCW dalam mengupayakan penguatan gerakan rakyat. Khususnya dalam membangun budaya anti korupsi melalui gerakan anti korupsi, yaitu: 1) Tergalangnya dukungan dari publik terhadap kerja-kerja pelembagaan gerakan sosial. 2)
Menguatnya pengetahuan, kemampuan dan peran kelompok warga dalam membentuk pospos pengaduan, zona antikorupsi dan sekretariat bersama sebagai sarana pemberian informasi dan advokasi publik 3) Terkonsolidasinya partisipasi aktif publik dan jaringan Organisasi Anti Korupsi untuk melakukan pendidikan dan kampanye publik dalam upaya melakukan pencegahan korupsi di sektor pelayanan publik, politik, dan hukum dan peradilan. Pada tahun 2018, program strategis MCW lebih dikembangkan dengan meningkatkan kapasitas dan kualitas manajemen kelembagaan MCW untuk mendukung advokasi kasus korupsi serta mendukung efektivitas kerja-kerja gerakan sosial antikorupsi serta meningkatkan kualitas dan kontinuitas agenda riset, monitoring, investigasi dan advokasi kasus korupsi di sektor pelayanan publik, korupsi politik, lembaga peradilan (Badan Pekerja MCW, 2017; 2018).

Pada negara demokrasi, setiap warga negara diberikan kebebasan dalam menyampaikan pendapatnya dan diberikan hak untuk berkumpul (berserikat). Sehingga para warga negara dapat melakukan kebaikan secara bersama sebagai perwujudan partisipasinya di ruang publik. Ruang publik yang dimaksud dapat berupa wilayah kota (perkotaan). Kota adalah bagian kecil dari sebuah negara, selanjutnya di reproduksi sebagai konsep negara lokal. Dimulai dari sinilah konsep peran warga negara dimulai sebagai agen politik yang memainkan peran penting dalam sejarah kewarganegaraan di peradaban barat. Dalam hal ini kota sebagai wadah warga negara dalam berperilaku sebagai subjek serta objek. Maksud dari subjek bahwa warga negara menjadi sosok yang berbudi luhur dengan pengembangan kesetiaannya kepada kota. Di sini kota menjadi tempat berkembang biak bagi kewarganegaraan aktif dan demokratis. Kota adalah tempat warga di habituasi ke dalam imajinasi demokrasi melalui latihan, pengalaman, dan pendidikan. Karena kota adalah tingkat pemerintahan yang paling dekat dengan warga negara dan dapat didekati serta diarahkan (Isin, 2002:308-309).

Sejatinya LSM memiliki peran penting dalam praktik kehidupan di masyarakat. Melalui perannya sebagai media alternatif, LSM dipandang mampu menjadi gerakan masyarakat kewargaan dengan melahirkan masyarakat sipil. Salah satu peran yang dapat dilakukan yaitu dengan menciptakan forum pendidikan kewarganegaraan. Pendidikan kewarganegaraan bahwasanya dapat dicapai sepanjang masa dan dalam situasi serta kondisi lingkungan apapun. Selanjutnya Winataputra (2012:34) berpendapat bahwa pendidikan kewarganegaraan yang bermuara pada gagasan "The Ideal Citizenship" sebagai "Informed and Reasoned Decision Maker" yang "competent, confident, and committed" harus terasah kompetensinya, kompetensi yang dimaksud, yaitu civic 
knowledge (pengetahuan kewarganegaraan), civic skill (keterampilan kewarganegaraan, dan civic disposition (watak kewarganegaraan), Maka dari itu pendidikan kewarganegaraan untuk masyarakat penting untuk lebih dikembangkan.

Pendidikan Kewarganegaraan memiliki pengaruh terhadap jalannya demokrasi dengan membentuk kehidupan masyarakat yang menjamin hak-hak warga negara, mempersiapkan warga negara untuk berpikir kritis dan bertindak secara demokratis (Fesnic, 2016: 966978). Pendidikan kewarganegaraan memperluas bentuk pendidikan moral yang demokratis dengan beralih dari teori ke dalam praktik, di mana orang dimungkinkan untuk membuat keputusan berdasarkan informasi, mengevaluasi kebijakan, dan berpartisipasi secara efektif dalam pemerintahan yang demokratis. Secara fungsional pendidikan kewarganegaraan adalah parameter sebagai pendidikan orang dewasa dan pembelajaran seumur hidup (Ngozwana, 2017: 3). Pada prinsipnya pendidikan kewarganegaraan merupakan hal yang paling mendasar dan efektif dalam mengembangkan peran warga negara secara aktif dengan turut serta membangun sistem demokrasi yang lebih baik (Molina-Giro'n, 2015: 47-72).

Di abad ke 21 ini memang menjadi tuntutan bahwa tujuan dari pendidikan kewarganegeraan yang diterima setiap warga negara bertujuan untuk membentuk warga negara yang aktif, serta turut dalam proses pembangunan berkelanjutan. Melalui keterlibatan warga (civic engagement) warga negara akan mampu mengembangkan pengetahuan, kecakapan, kebajikan, dan kebiasaan yang membuat demokrasi dapat bekerja secara proporsional. Asosiasi-asosiasi masyarakat kewargaan dapat menjadi kekuatan tanding (countervailing) untuk melawan penyalahgunaan kekuasaan dalam pemerintahan.

Semakin terbukanya ruang politik, semakin membuka lebar pergerakan masyarakat dalam berekspresi di berbagai bentuk organisasi politik baik pemerintah maupun non pemerintah. Tidak ada lagi hegemoni kekuasaan, tidak ada ideologi absolutisme yang menjadi dasar pijakan masyarakat dalam menentukan peradaban. Iklim segar yang dibawa oleh angin reformasi menciptakan keleluasaan-keleluasaan bagi masyarakat dalam menyalurkan aspirasinya. Hak asasi manusia yang dimiliki setiap orang tidak dapat dikurangi dalam keadaan apapun. Tidak ada lagi pengontrolan masyarakat melalui pembatasan kegiatan partai politik atau organisasi sosial yang ditujukan untuk menciptakan kestabilan politik.

Pada konteks komparatif di beberapa negara demokrasi baru, para ilmuwan politik menekankan bagaimana peran organisasi masyarakat sipil dalam demokrasi (Fioramonti dan Fiori, 2010:26-27): Pertama, organisasi masyarakat sipil menciptakan hubungan formal untuk menghubungkan berbagai kepentingan dalam masyarakat dan juga untuk memfasilitasi komunikasi politik antara warga negara dan negara; Kedua, organisasi masyarakat sipil dapat menantang dan menyeimbangkan kekuatan negara apakah upaya negara untuk meningkatkan akuntabilitasnya kepada publik meningkat; Ketiga, sebagai bagian dari indikasi penting dalam penilaian demokratis, para anggota organisasi masyarakat sipil harus mendukung partisipasi politik; Keempat, kekuatan masyarakat sipil harus bertindak sebagai pembela kepentingan publik jika ada hubungan dengan negara, yang ditunjukkan dari penegakan moralitas publik dan kritik terhadap politisi dan pejabat publik; dan poin terakhir adalah masyarakat sipil harus bertindak sebagai faktor eksternal dalam pendalaman demokrasi yang melindungi demokrasi dari segala gangguan eksternal dan internal dan politik yang tidak stabil. Oleh karena itu, jika Organisasi Masyarakat Sipil memperkuat peran-peran ini, mereka memastikan adanya perubahan politik yang signifikan di setiap negara.

Konsep modern masyarakat sipil perlu memiliki dimensi moral, normatif yang jelas. Nilainilai moral dalam hal ini dapat berupa kejujuran, keadilan, keikhlasan, dan tanggung jawab. Dalam istilah klasik tentang optimisme melibatkan daya tarik moral untuk hidup lebih beradab. Berkaitan erat dengan konsep peradaban dalam membentuk masyarakat yang baik (Pérez-Díaz, 2014: 814-815). Tujuan dasar dari peran serta masyarakat adalah menghasilkan input dan output yang berupa persepsi yang berguna bagi warga negara dan masyarakat yang memiliki kepentingan (public interest) dalam meningkatkan kualitas pengambilan keputusan, karena dengan melibatkan masyarakat yang berkepentingan, para pengambil keputusan dapat mempertimbangkan pandangan, kebutuhan dan penghargaan dari kelompok masyarakat tersebut. Kemudian akan dituangkan kedalam sebuah bentuk konsep. Lembaga swadaya masyarakat sebagai lembaga advokasi dapat memilih bentuk kemitraannya antara sebagai keterlibatan kritis (critical engagement) dan keterlibatan konstruktif (constructive engagement).

Melalui keterlibatan warga (civic engagement), warga negara akan mampu mengembangkan pengetahuan, kecakapan, kebajikan, dan kebiasaan yang membuat demokrasi dapat bekerja secara proporsional. Selanutnya asosiasi-asosiasi masyarakat kewargaan dapat menjadi kekuatan tanding (countervailing) dalam mengatasi berbagai persoalan masyarakat. Dalam proses interaksi yang melibatkan warga negara, terjadi proses sosialisasi yang bertujuan agar pihak yang dididik mematuhi kaidah-kaidah dan nilai-nilai yang dianut oleh masyarakat. 
Dalam proses ini tentunya dibutuhkan peran warga negara dalam mengimplementasikan dan mempromosikan kebijakan, tindakan, dan perbuatan yang konsisten dengan nilai-nilai seperti hak asasi manusia, keadilan sosial, dan kesetaraan. Dalam bahasa Banks (2017: 366369) peran warga negara semacam itu disebut sebagai warga negara yang transformatif, yang mengambil tindakan untuk mengaktualisasikan nilai-nilai dan prinsip-prinsip moral melampaui negara-negara-bangsa dan batas-batas nasional. Warga negara transformatif dapat digambarkan ke dalam konsepsi warga negara yang baik (bertanggung jawab secara pribadi, partisipatif, dan berorientasi pada keadilan).

Warga negara transformatif yang juga sebagai warga negara partisipatif tentunya akan secara aktif berpartisipasi dalam urusan-urusan sipil dan kehidupan sosial masyarakat baik di tingkat lokal, negara bagian (provinsi), maupun nasional. Wong, Lee, Chan, dan Kennedy (2016: 5) mempertegas terhadap apa yang telah diuraikan oleh Banks (2017). Mereka menyebut kewarganegaraan sebagai koneksi politik dan moral individu antara negara dengan masyarakat. Kewarganegaraan merupakan bagian dari komunitas politik yang terlibat secara langsung dalam serangkaian hubungan antara hak, kewajiban, partisipasi, dan identitas.

Winarno (2009:10) menyebutkan bahwa identitas kewarganegaraan pada akhirnya bermuara sebagai civic virtue atau kebajikan warga negara yang perlu dibangun demi menumbuh kembangkan karakter kewarganegaraan dan komitmen kewarganegaraan. Individu yang bajik (virtue) pasti memiliki karakteristik tidak sebagai seseorang melainkan sebagai publik yang berkualitas yang mampu menyesuaikan dengan standar-standar yang tertulis dalam UU, norma, atau adat istiadat secara keseluruhan, dan warga negara yang bajik mampu menekan kepentingan pribadi dengan menekankan kepentingan publik. Snow (2018: 412-419) menambahkan bahwa warga negara yang bajik dapat dijadikan sebagai promotor dalam menjunjung nilai-nilai demokrasi, dan berkomitmen pada proses demokrasi.

\section{Peran MCW dalam Membangun Budaya Anti-Korupsi}

$\mathrm{P}$ ada era perkotaan, terjadi penurunan budaya kewarganegaraan dalam perkembangan demokrasi, sebagai buktinya semakin merosotnya tingkat kepercayaan warga negara atau warga kota terhadap pemerintah dan aktivitas-aktivitas politik lainnya. Hal ini dapat diidentifikasi dari masifnya kejahatan korupsi di tingkat daerah khususnya di wilayah Malang Raya. Maka penting adanya revitalisasi dalam membangun kembali budaya kewarganegaraan oleh warga negara perlu untuk kembali di angkat eksistensinya. Reddel and Woolcock dalam
Brackerz, dkk (2005:14) menawarkan cara yaitu dengan melibatkan lebih luas cakupan warga negara/warga kota sebagai stakeholders dalam pembuatan keputusan di suatu daerah akan menjadi pembelajaran tersendiri bagi masyarakat, misalnya dalam mengatasi (counterattack) atau sinisme dan animo masyarakat terhadap pemerintah. Bentuk kegiatan semacam itu tentunya dapat melahirkan identitas budaya kewargaan tersendiri.

Dengan mengadopsi pandangan Marx, Prasetijo (2015: 66) menjelaskan jika ingin mengubah keadaan, kaum kelas Proletar haruslah dapat mengorganisir diri untuk melawan kaum Boujouis. Dalam penjelasan Prasetijo (2015: 66), dapat dimaksudkan sebagai perjuangan untuk mencapai keadilan dengan mengubah keadaan yang tengah berlangsung. Marx mengenalkan pentingnya ideologi dalam perjuangan, karena ideologi digunakan sebagai alat acuan untuk melakukan perjuangan. Marx secara luas menjelaskan bagaimana peran ideologi memiliki keterkaitan dengan budaya, dalam pemahamannya budaya merupakan nilainilai revolusi yang menjadi dasar sebuah pergerakan, dan inilah makna sebenarnya dari ideologi.

Selaras dalam penjelasan Prasetijo (2015: 66) sebuah perjuangan harus berlandaskan pada ideologi yang mendasarinya. Malang Corruption Watch merupakan lembaga swadaya masyarakat (LSM) yang lahir pada 31 Mei 2000, terinspirasi oleh keberadaan Indonesia Corruption Watch (ICW) pada saat itu. Malang Corruption Watch sebagai lembaga pergerakan memiliki ideologi tersendiri yaitu melawan kejahatan korupsi. Hal ini terumuskan dalam visi MCW yaitu terciptanya masyarakat madani yang humanis, beradab, bermartabat dan berdaulat dengan mengupayakan terciptanya tatanan birokrasi, politik, ekonomi dan hukum yang bebas dari korupsi, kolusi dan nepotisme (Badan Pekerja MCW, 2017).

Dalam pemberantasan kasus-kasus korupsi yang menjadi tugas berat adalah melakukan konsolidasi gerakan rakyat. Membangun kesadaran kritis agar rakyat memahami bahwa korupsi telah merusak sendi-sendi kehidupan. Maka penguatan gerakan rakyat menjadi agenda penting dalam memerangi korupsi. Agar tindakan semacam itu menjadi sebuah budaya dalam masyarakat.

Kebudayaan merupakan blue print of behavior, dengan memberikan pedoman kepada masyarakat untuk berperilaku dan bertindak. Menurut Saleh dan Munif (2015:311) menyebutkan ciri-ciri umum kebudayaan adalah dipelajari, diwariskan dan diteruskan, hidup dalam masyarakat, dikembangkan dan berubah, serta berintegrasi. Berdasar pada pedoman yang warga patuhi, masyarakat membentuk prosedurprosedur dalam mencapai tujuan yang diinginkan. 
Pendidikan antikorupsi perlu dilakukan dalam upaya pemberantasan korupsi. Pemberantasan korupsi harus dilaksanakan dengan konsisten, bukan hanya menangkap dan mengadili pelaku korupsi, namun lebih kepada memberikan pemahaman dan kesadaran yang dilakukan melalui sosialisasi, kampanye antikorupsi lokal, nasional, dan lintas negara (Gephart, 2016: 49-77). Korupsi memang menjadi fenomena yang kompleks dan multifaset. Dalam mengatasi persoalan korupsi, reformasi antikorupsi dapat digambarkan sebagai "maraton dan bukan spirit".

Mengendalikan korupsi dapat dilakukan melalui alat yang berupa struktur hukuman dalam masyarakat. Agar hukuman benar-benar menjadi alat dalam menangkal korupsi maka sistem hukum dan budaya suatu negara harus efektif (Chowdhury, Desai, \& Audretsc, 2018: 44). Menengok keberhasilan Singapura dijelaskan dalam artikel Quah (2017), bahwa kemauan politik sangat penting untuk keberhasilan pelaksanaan perjuangan dalam memerangi kejahatan korupsi (anti-korupsi). Karena bentuk sikap politis dapat mengubah "budaya korupsi" jika mereka ingin melakukannya.

Sementara Malang Corruption Watch sebagai gerakan masyarakat sipil dalam membangun budaya anti korupsi di tingkat daerah tidak hanya melakukan monitoring, investigasi, dan pengawasan saja. Dalam memerangi kejahatan tindak pidana korupsi ini, MCW mengembangkan beberapa kegiatan diantaranya adalah Pendidikan Politik Rakyat, Kelompok Warga Mengawal Pelayanan Publik, Mengkampanyekan Gerakan Anti Korupsi, Dunia Digital Menjadi Arus Utama Informasi, dan Sekolah Anti Korupsi (Badan Pekerja MCW, 2017; 2018). Seperti yang dapat dijelaskan dibawah ini:

\section{a. Pendidikan Politik Rakyat}

Dalam pendidikan politik rakyat yang dilakukan oleh Malang Corruption Watch merupakan proses dalam membangun kesadaran kritis masyarakat dengan diawali memberikan pemahaman hak dan kewajiban sebagai warga negara. Melalui pengetahuan tentang hak dan kewajiban sebagai warga negara, maka masyarakat akan turut ikut serta dalam membangun partisipasi aktif di masyarakat. Beberapa metode dan saran yang dikembangkan oleh MCW dalam pendidikan politik rakyat ini adalah sekolah rakyat dan forum warga (Badan Pekerja MCW, 2017).

\section{b. Sekolah Rakyat}

Sekolah rakyat merupakan sarana untuk memberikan transfer pengetahuan dan pengalaman, utamanya kepada aktor warga. Tujuan dari sekolah rakyat adalah menyiapkan aktor-aktor warga yang siap dan kompeten untuk melakukan pengorganisasian dan advokasi di wilayah masing-masing. Selain itu melalui aktor-aktor yang berkompeten akan mampu membangun zona-zona anti korupsi dengan membuka pos pengaduan dan melakukan pendidikan publik kepada warga sekitarnya. Bagi MCW sekolah rakyat sebagai wadah dalam meningkatkan kemampuan kapasitas serta keterampilan dalam melakukan advokasi. Materi yang diberikan lebih banyak tentang filosofis gerakan sosial dan HAM sehingga mampu membentuk nalar kritis warga dalam menghadapi problem sosial di sekitarnya (Badan Pekerja MCW, 2017; 2018).

\section{c. Forum Warga}

Berdasarkan data Badan Pekerja MCW, untuk membangun kesadaran kritis warga dilakukan aktivitas rutin berupa forum warga yang tersebar di berbagai wilayah Malang Raya. Kegiatan ini dilakukan sebagai bentuk diaspora gerakan pengorganisian. Berikut detail forum warga dan kelompok warga yang bertujuan dalam peningkatan kapasitas dan monitoring kebijakan publik (Badan Pekerja MCW, 2017).

Tercatat dalam laporan MCW tahun 2018 forum warga telah berlangsung di beberapa wilayah di Malang Raya. Pertama, di Kota Malang, perkembangan forum warga telah berlangsung di seluruh kecamatan, seperti Kecamatan Lowokwaru, Sukun, Kedungkandang, Klojen, dan Blimbing. Bentuk pendidikan publik tentang antikorupsi dalam forum warga ini menghasilkan fase perkembangan yang terbagi menjadi tiga fase, yaitu diseminasi informasi, peningkatan kapasitas, dan kemampuan advokasi yang dilakukan oleh forum warga tersebut (Badan Pekerja MCW, 2018).

Kedua, di Kota Batu, perkembangan forum warga yang telah berlangsung di lakukan dalam Forum PKK RT 2 RW 17 dan Front Warga Sumberejo. Forum PKK RT 2 RW 17 merupakan salah satu simpul belajar warga yang sejauh ini mendapat pendampingan dan di organisir oleh MCW. Bentuk pendidikan publik dalam forum ini adalah dengan melibatkan diri dalam agenda PKK yang secara rutin dilakukan 2 kali dalam satu bulan. Proses pendidikan publik dalam forum ini menitik beratkan pada anggota forum PKK yang hadir dalam agenda tersebut dapat mendengar, memahami, dan memberikan pandangan terhadap problem yang terjadi, baik di lingkungan sekitar maupun Kota Batu. Sedangkan Front Warga Sumberejo terdiri dari 12 orang warga yang mulanya mereka adalah korban atas kebijakan pemungutan PBB yang diduga diselewengkan oleh Petugas Pemerintah Desa. Front Warga Sumberejo bekerja sama dengan MCW dengan menindaklanjuti aduan tersebut dengan melakukan pertemuan dan pembicaraan tentang kronologis masalah, strategi pendampingan, dan membangun kesepakatan kolektif untuk melakukan advokasi 
bersama kepada Pemerintah Desa (Badan Pekerja MCW, 2018).

Ketiga, di Kabupaten Malang, forum warga yang telah berlangsung dilakukan melalui beberapa forum seperti Forum Warga Mondoroko, Forum Warga Glanggang Pakisaji, Forum warga Gondanglegi, Forum Warga Turen Sananrejo, dan Forum Warga Tumpang. 1) Forum Warga Mondoroko yang terbentuk karena masalah yang sangat besar yakni lapangan sepak bola yang telah lama di kuasai oleh RW 19 Mondoroko di ganggu oleh pemodal. Melalui pertemuan rutin dengan MCW sebulan sekali, mulai dari Ketua RT, Ketua RW, masyarakat mondoroko telah mengalami peningkatan kapasitas dan mampu melakukan advokasi secara mandiri. 2) Forum Warga Glanggang Pakisaji terbentuk dari inisiasi salah satu warga yang secara rutin setiap seminggu sekali forum warga ini membahas isu-isu pembangunan desa, misalnya mekanisme Musrembang di Desa, isuisu pendidikan dan kesehatan serta isu administrasi kependudukan. Masyarakat dalam forum warga ini telah mampu dan berani melakukan advokasi terhadap haknya. 3) Forum Warga Gondanglegi yang di inisiasi oleh salah satu warga ini masih pada tahap pengembangan dengan melakukan kerja sama dengan Karang taruna Desa. 4) Forum Warga Turen Sananrejo yang terbentuk karena keresahan warga terhadap berdirinya menara Telekomunikasi yang sudah berdiri selama 10 tahun terakhir. Melalui kerja sama dengan MCW dengan melakukan pertemuan rutin selama satu bulan sekali, forum ini telah berani melakukan proses advokasi secara mandiri dan telah melakukan hearing bersama-sama DPR untuk memperoleh haknya untuk bebas dari tower. 5) Forum Warga Tumpang yang di inisiasi oleh Warga untuk konsultasi masalah konsep pembangunan Desa. Pertemuan yang telah berlangsung yakni rutin dilakukan selama satu bulan sekali. Pihak MCW telah melakukan pendidikan publik kepada warga dengan materi berupa pembangunan desa, pembangunan jaringan komunikasi dan kedekatan, dan tentang pemetaan sosial (Badan Pekerja MCW, 2018).

Terdapat beberapa tahapan dalam proses transformasi pengetahuan warga (civic knowledge), pertama peningkatan kapasitas pengetahuan warga; kedua, keterlibatan warga dalam agenda advokasi praktis; dan ketiga, pengetahuan warga meningkat dan secara mandiri mampu melakukan agenda advokasi dilingkunganya.

\section{d. Kelompok Warga Mengawal Pelayanan Publik}

Dalam kegiatan kelompok warga mengawal pelayanan publik, MCW bersama warga Malang Raya membentuk Forum Masyarakat Peduli Pendidikan (FMPP) yang fokus dalam pemantauan dan advokasi pelayanan pendi- dikan. Harapannya dengan adanya FMPP mendorong sekolah bersih dari pungli. Pada tahun 2018 MCW bersama FMPP lebih mengembangkan fokus mereka dengan revitalisasi peran dan fungsi Komite Sekolah (Badan Pekerja MCW, 2017; 2018).

Sedang pada awal tahun 2017 dibentuk kelompok masyarakat yang fokus pada pemantauan dan advokasi pelayanan kesehatan yaitu Forum Masyarakat Peduli Kesehatan (FMPK). Adanya FMPK dapat menggugat pelayanan kesehatan yang tidak pro rakyat. Pada tahun 2018 MCW dengan FMPK melakukan kerja sama dengan fokus terhadap pengawalan tentang permasalahan pendataan warga miskin untuk penerima bantuan iuran (PBI), perubahan layanan kesehatan di setiap puskesmas, mendorong adanya universal health coverage (UHC), dan perubahan peraturan daerah (Perda) kesehatan Kota Malang (Badan Pekerja MCW, 2017; 2018).

\section{e. Mengkampanyekan Gerakan Anti Korupsi}

Penguatan warga dilakukan melalui gerakan bersama rakyat dalam pencegahan korupsi dapat dilakukan melalui pendidikan publik. Dalam menyebarkan gerakan anti korupsi MCW menggunakan berbagai metode, salah satunya melalui kampanye anti korupsi. Kampanye publik sebagai bentuk edukasi anti korupsi kepada masyarakat menjadi peran penting sebagai gerakan anti korupsi. Contohnya yang telah dilakukan oleh MCW yaitu dalam membangun gerakan anti korupsi dilakukan melalui bentuk bioskop warga dan pagelaran seni anti korupsi. Tujuannya adalah memberikan dampak kepada masyarakat dengan menyatukan perspektif terhadap kejahatan korupsi sebagai musuh bersama (Badan Pekerja MCW, 2017).

Pada tahun 2018 MCW lebih mengembangkan perannya dalam membangun budaya antikorupsi melalui campaign atau kampanye gerakan antikorupsi seperti cerita jagongan (diskusi) rakyat dalam memfasilitasi pertemuan antara masyarakat dengan penyelenggara negara dan bersama akademisi atau praktisi. Pertemuan dengan tajuk jagongan ini misalnya berdiskusi tentang penyelenggaraan pemilukada di Kota Malang dengan mengundang Komisi Pemilihan Umum Daerah (KPUD) dan Panitia Pengawas (Panwas) Kota malang yang menghasilkan kesepakatan agenda pengawalan bersama pelaksanaan Pilkada Kota Malang yang berintegritas.

Selanjutnya ada kegiatan seperti istighosah antikorupsi, pemeran kartun antikorupsi, dan media sosial. Pertama, istighosah antikorupsi, kegiatan ini dikemas dengan mengangkat tema "Malang Darurat Korupsi" yang merupakan respon terhadap 41 DPRD Kota Malang yang ditahan oleh KPK. MCW dalam kegiatan ini mengajak seluruh elemen masyarakat Kota Malang baik driver ojek, pedagang, ibu rumah 
tangga, sopir angkot, guru, dosen, mahasiswa, buruh pabrik, petani, pemuda, agamawan, hingga masyarakat yang tergabung dalam Aliansi Masyarakat Antikorupsi (AL-MAK). Kedua, pameran kartun antikorupsi, kegiatan ini bertujuan untuk merespon korupsi yang terjadi di Malang Raya dan secara khusus respon atas penahanan 41 anggota DPRD Kota Malang. Pameran kartun antikorupsi dihadiri oleh berbagai macam kalangan mahasiswa hingga orang tua, khususnya para siswa SMP Kota Malang dan SMA Negeri 1,3, dan 4 Kota Malang yang berkunjung bersama guru. Mereka berdiskusi tentang antikorupsi bersama KPK dan membuat kartun bersama kartunis Dhany Valiandra. Ketiga, media sosial, yang menjadi sumber informasi utama bagi semua kalangan masyarakat Indonesia khususnya Malang Raya. Bagi MCW pengembangan media sosial menjadi prioritas utama dalam melakukan kampanye antikorupsi. Media sosial yang dimiliki MCW meliputi, Web yang beralamatkan https://mcwmalang.org/; IG beralamatkan @mcwngalam; Facebook beralamatkan Malang Corruption Watch; dan Twitter beralamatkan @MCWngalam. Adanya media sosial mempermudah MCW melakukan kampanye dengan berbagai konten yang dianggap relevan, seperti infografis hasil analisa kebijakan, kasus, dan beberapa data lainnya yang penting untuk disampaikan kepada publik.

\section{f. Sekolah Anti Korupsi}

Sebuah pendekatan model pendidikan anti korupsi pertama di Indonesia ini menjadi salah satu pilihan metode gerakan yang paling mujarab untuk menyemai gerakan anti korupsi. Model gerakan sekolah anti korupsi pun kemudian mulai di replikasi dan muncul bak jamur di musim hujan. Malang Corruption Watch melakukan inovasi terkait pelaksanaan sekolah anti korupsi dengan berbagai penyesuaian. Ada dua bentuk Sekolah Anti Korupsi yakni Sekolah Anti Korupsi (SAKTI) Terpusat dan Sakti On Campus. Kedua program ini memiliki dua pendekatan berbeda. Bila SAKTI terpusat sebagai pencetak relawan kader di Malang Corruption Watch, sementara pada pelaksanaan SAKTI ON Campus merupakan kerja sama dengan organisasi mahasiswa intra kampus untuk membangun model sebuah pelatihan secara berkelanjutan (Badan Pekerja MCW, 2017).

Beberapa kegiatan diatas merupakan bentuk upaya yang di lakukan MCW dalam membangun budaya anti korupsi di tingkat daerah khususnya Malang Raya. Agar upayaupaya tersebut dapat menghasilkan sebuah budaya yang melawan terhadap kejahatan korupsi. Maka dalam orientasinya membangun budaya antikorupsi dapat mengadopsi sebuah konsep tindakan dalam memerangi kejahatan korupsi yang di gagas oleh Gong and Wang
(2012: 571-572) dengan zero tolerance for corruption. Bentuk toleransi terhadap korupsi tersebut dapat dilihat dari bagaimana orang memahami aturan dan etika sosial dan bagaimana setiap orang bereaksi terhadap perilaku menyimpang. Secara khusus, apa yang disebut sebagai zero tolerance mengacu pada kecenderungan untuk menolak godaan terlibat dalam korupsi dalam perilaku sendiri dan juga mempertimbangkan perilaku korup orang lain sebagai etika yang tidak dapat diterima. Toleransi nol memiliki atribut yang dapat diukur yang mencakup, tidak menunjukkan simpati dengan korupsi; bersedia melaporkan contohcontoh korupsi yang menjadi perhatian seseorang; mendukung penegakan hukum yang ketat; dan bersikap keras bahkan untuk pelanggaran kecil (Gong and Wang, 2012: 572).

Konsep zero tolerance for corruption yang di gagas oleh Gong and Wang (2012) akan berdampak secara implisit maupun eksplisit dalam membangun budaya antikorupsi dengan semkin tertanamnya prinsip-prinsip antikorupsi di berbagai lini. Prinsip-prinsip tersebut meliputi akuntabilitas, transparansi, kewajaran (fairness), kebijakan, dan adanya kontrol terhadap kebijakan tersebut (Rosikah dan Listianingsih, 2016: 84-96).

Pada hasilnya MCW sebagai gerakan masyarakat sipil adalah mitra lembaga negara seperti legislatif, yudikatif, dan eksekutif bertujuan untuk membangun pemerintahan yang baik (good governance) (Saha, 2014: 46-47). Pemerintah yang baik seharusnya bertumpu pada virtuous triangle atau segitiga berbudi luhur, yaitu antara negara, pasar, dan sektor ketiga (LSM/masyarakat sipil). Munculnya LSM sebagai sektor ketiga dalam konsep pemerintahan yang baik tersebut karena LSM adalah bagian dari proses konsultasi yang membantu menyusun instrumen kebijakan baru. (Lewis, 2010: 335336).

Unsur-unsur penting dari pemerintahan yang baik adalah dapat diidentifikasi dalam sepuluh karakteristik. Salah satunya adalah adanya bentuk pemerintahan sebagai media independen, yaitu sebagai cara fungsional untuk meningkatkan kesadaran publik, menyelidiki dan melaporkan korupsi (Saha, 2014: 47). Dalam pemerintahan yang baik, pemerintahan lokal memiliki peran penting untuk bermain dalam melaksanakan pendekatan-pendekatan yang akan mengarah pada keseimbangan antara sifat rasional dan irasional manusia (Bello dan Dola, 2014: 246)

\section{KESIMPULAN}

K eberhasilan memberantas korupsi dapat dilihat dari keterlibatan berbagai pihak dalam memberantas korupsi. Khususnya melalui Lembaga Swadaya Masyarakat "Malang 
Corruption Watch" sebagai bentuk gerakan masyarakat sipil yang menjunjung nilai zero tolerance for corruption dalam mewujudkan demokrasi, partisipasi, dan akuntabilitas melalui beberapa kegiatan yang mereka lakukan seperti pendidikan politik rakyat, sekolah rakyat, forum warga, kelompok warga mengawal pelayanan publik, melakukan kampanye gerakan anti korupsi, dan sekolah anti korupsi. Demi mewujudkan pemerintahan yang baik dan bersih membutuhkan peran LSM seperti Malang
Corruption Watch dalam meningkatkan prinsipprinsip antikorupsi di daerah.

\section{E. UCAPAN TERIMAKASIH}

A Artikel ini merupakan penulisan ulang dari sebagian naskah tesis di Program Studi Pendidikan Pancasila dan Kewarganegaraan Program Pascasarjana Universitas Negeri Yogyakarta. Penulis menyampaikan ucapan terima kasih kepada pembimbing tesis yaitu Dr. Samsuri, M.Ag. yang telah membimbing penulis dalam penyusunan artikel ini.

\section{DAFTAR PUSTAKA}

Badan Pekerja Malang Corruption Watch. (2017). Laporan Akhir Tahun 2017. Malang: Malang Corruption Watch. . (2018). Laporan Akhir Tahun 2018. Malang: Malang Corruption Watch.

Banks, J. A. (2017). Failed Citizenship and Transformative Civic Education, Educational Researcher. Vol. 46, No. 7, pp. 366-377. DOI: 10.3102/0013189X17726741.

Bello, A., dan Dola, K. (2014). Sustainable development and the role of local governance: Experience from malaysian model regions. Journal of Humanities and Social Science. Vol 4, No.1, pp. 268-280.

Brackerz, N., dkk. (2005). Main Report Community Consultation And The Hard To Reseacrh: Concept And Practice In Victorian Local Government. Australia: Swinburne Institute for Social Reseacrh.

Chowdhury, F., Desai, S. \& Audretsch, D. B. (2018). Corruption, Entrepreneurship, And Social Welfare A Global Perspective. Cham: Springer Nature.

Deliversky, J. (2016). Preventing Corruption In The Education System. Journal Of Educational And Instructional Studies. Vol. 6, No.1.

Fesnic, F. N. (2016). Can civic education make a difference for democracy? Hungary and Poland compared. Political Studies. Vol. 64, No. 4, pp. 966-978. https://doi.org/10.1111/14679248.12215.

Fioramonti, L. and Fiori, A. (2010). "Civil Society after Democracy: The Evolution of Civic Activism in South Africa and Korea." Journal of Civil Society. Vol. 6, No.1, pp. 23-38.

Gephart, M. (2016). Local embedding of international discourse: Chile and the international and transnational anti-corruption campaign. International Relations. Vol. 30, No.1, pp. 49-77.

Gong, T., dan Wang, S. (2012). Indicators and Implications of Zero Tolerance of Corruption: The Case of Hong Kong. Springer: Social Indicators Research. Vol. 112, No. 3, pp. 569-586.

Indonesia Corruption Watch. (2016). Menyemai Semangat Antikorupsi: Annual Report 2016. Jakarta: ICW.

Isin, F Engin. (2002). City, Democracy and Citizenship: Historical Images, Contemporary Practices. London: Sage Publications Inc.

Jiang, G. (2017). Corruption Control In Postreform China: A Social Censure Perspective. Singapore: Springer Nature.

Kubbe, I. \& Engelbert, A. (2018). Corruption And Norms: Why Informal Rules Matter. Cham: Springer Nature.

Lewis, D. (2010). Political ideologies and non-governmental organizations: an anthropological perspective, Journal of Political Ideologies. Vol. 15, No.3, pp. 333-345, DOI: 10.1080/13569317.2010.513877.

Molina-Girón, L. A. (2015). Educating active citizens: what roles are students expected to play in public life?, In Sandi Kawecka Nenga, Jessica K. Taft (Ed) Youth Engagement: The CivicPolitical Lives of Children and Youth, Vol. 16 Emerald Group Publishing Limited, pp. 47-72. Doi:10.1108/S1537-4661(2013)0000016007.

Ngozwana, N. A. (2017). Civic education in Lesotho: implications for teaching of democratic citizenship, International Journal of Lifelong Education. Vol. 36, No. 5, pp. 526-540. DOI: 10.1080/02601370.2017.1304460.

Pérez-Díaz, V. (2014). Civil society: A multi-layered concept, Current Sociology Review. Vol. 62, No. 6, pp. 812-830. DOI: 10.1177/0011392114533115.

Prasetijo, A. (2015). Pergerakan Sosial: Antara Marxian dan Non Marxian, Jurnal Antropologi: Isu-isu Sosial Budaya. Vol. 17, No. 1, pp 65-70. 
Puspito, N. T., Elwina S M., Utari, I. S., dan Kurniadi, Y. (2011). Pendidikan Anti Korupsi untuk Perguruan Tinggi. Jakarta: Kementerian Pendidikan dan Kebudayaan RI.

Quah, J. S.T. (2017). Five success stories in combating corruption: lessons for policy makers. Asian Education and Development Studies. Vol. 6, No.3.

. (2017). Singapore's success in combating corruption: lessons for policy makers. Asian Education and Development Studies. Vol. 6, No.3.

Rosikah, C. D., dan Listianingsih, D. M. (2016). Pendidikan antikorupsi: Kajian antikorupsi teori dan praktik. Jakarta: Sinar Grafika.

Saha, S. K. (2014). Corruption and good governance: The case of Bangladesh. Journal of Social Sciences. Vol. 22, No. 2, pp. 45-52.

Saleh, K. \& Munif. (2015). Membangun Karakter Budaya Politik dalam Demokrasi. Jurnal ADDIN. Vol. 5, No.2, pp. 309-332.

Snow, N. E. (2018). Hope as a democratic civic virtue. Metaphilosophy. Vol. 49, No. 3, pp. 407-426. https://doi.org/10.1111/meta.12299.

Tim Penyusun Laporan KPK. (2018). Laporan Tahunan 2017: Demi Indonesia Untuk Indonesia. Jakarta: Komisi Pemberantasan Korupsi.

Transparency International. (2017). Corruption Perspection Index (CPI) 2016. This work from Transparency International. International. (2018). Corruption Perspection Index (CPI) 2017. This work from Transparency

Winarno. (2009). Kewarganegaraan Indonesia dari Sosiologi Menuju Yuridis. Bandung: Alfabeta.

Winataputra, U.S. (2012). Pendidikan Kewarganegaraan Dalam Perspektif Internasional. Bandung: Widya Aksara Press.

Wong, K. L., Lee, C. K. J., Chan, K. S. J. \& Kennedy, K. J. (2016). Constructions of civic education: Hong Kong teachers' perceptions of moral, civic and national education, Compare: A Journal of Comparative and International Education. Vol. 47, No. 5, pp. 628-646. DOI: 10.1080/03057925.2016.1262756.

Zed, M. (2008). Metode Penelitian Kepustakaan. Jakarta: Yayasan Obor Indonesia. 